\title{
UTILISATION OF NAKED OATS AND BARLEY IN THE FEED OF BROILERS AND LAYING HENS
}

\author{
J. GUILLAUME et C. CALE'T \\ Station de Recherches avicoles, \\ Centre de Recherches de Tours, I. N.R. A., \\ Nouzilly, 37380 Monnaie
}

Three varieties of hulless cereals : two oats and one barley were compared to maize (trial I), to maize, wheat and normal or dehulled oats and barley (trial 2) as main components of isocaloric diets in growing chicks. Comparisons were made either on the basis of lysine level (trial $\mathbf{r}$ ) or on the basis of protein level (trial 2). The growth allowed by these cereals was never better than that obtained with maize or wheat. The proteins seem to be responsible for this depression. However, hulless barley appears to be a good cereal for laying hens, at least until 30 p. Ioo of the diet. The energy value of hulless barley and hulless oats measured on chick was 3 and $3.3^{8} \mathrm{kcal} / \mathrm{g}$ respectively.

\section{EFFECTS OF RAPESEED OIL MEAL ON THE GROWTH OF GUINEA FOWL. COMPARISON WITH THE CHICK}

\author{
J. C. BLUM, J. GUILlaUmE et B. LECLERCQ \\ Station de Recherches avicoles, I. N.R.A., \\ Centre de Recherches de Tours \\ Nouzilly, 37380 Monnaie
}

The effects of rape seed oil meal were studied at 3 levels (5, 10 and 20 p. Too of the diet) in the growing Guinea fowl from o to 6 weeks and from 6 to 12 weeks of age, as well as in the growing chick from o to 4 weeks. The trial with chicks indicated that the sample of rape seed oil meal was not very toxic. However, in guinea fowl it induced a growth depression and an incidence of perosis during the starting period. The higher the percentage of rape seed oil meal the more pronounced were these effects. After 6 weeks of age, rape seed meal was tolerated by the birds as well when they had been fed this oil meal during the starting period as when they had not. Rape seed meal even improved the feed efficiency. 